\title{
Trending Applications of 3D Printing: A Study
}

\author{
Rakesh Kumar ${ }^{1}$ and Santosh Kumar ${ }^{2}$ \\ ${ }^{1}$ Assistant Professor, Department of Mechanical Engineering, Chandigarh Group of College Landan, Mohali, India \& \\ Research Scholar, Department of Mechanical Engineering, Chandigarh University, Mohali, India \\ ${ }^{2}$ Assistant Professor, Department of Mechanical Engineering, Chandigarh Group of College Landan, Mohali, India \& \\ Research Scholar, Department of Mechanical Engineering, IKG Punjab Technical University, Punjab, India. \\ E-mail: rk05691@gmail.com, santoshdgc@gmail.com
}

\begin{abstract}
The popular name which is known by the most people and the market is $3 \mathrm{D}$ printing. It is an emerging manufacturing technology used to fabricate, real life parts using CAD data by adding material in layer fashion in distinct form (solid, liquid and powder). 3D printing technology is the reverse of conventional/subtractive manufacturing, owing to its design flexibility, customization, material complexity, size range, waste minimization, tool less and the ability to manufacture complicated shapes. This review paper aims to provide a comprehensive overview of distinct 3D printer applications in different sector. In addition, this review paper summarizes the merits, demerits, future and challenges, so that this review paper could become the torch bearer for the futuristic researchers working in the area of $3 D$ printing.

Keywords: 3D Printing, Computer Aided Design, Applications, Challenges, Future Scope.
\end{abstract}

\section{INTRODUCTION}

Additive manufacturing is also known as 3D printing/ rapid prototyping/desktop manufacturing/solid free form fabrication technique used for the manufacturing of intricate shapes and structure from 3D CAD model data $[1,2]$. This process was $1^{\text {st }}$ started by Charle Hull, in 1980s called "stereo lithography" (SL) [3]. After several experimental investigations he starts writing the code, which understand the printer and later on (in 1988) he sold $1^{\text {st }}$ 3D printing machine for $\$ 100,000$. After that, several distinct companies such as Solidscape etc. manufactured 3D printing machine for commercial application. With the advancement in technology, recently, 3D printing machine is utilized for production of implants, automobile parts, bridges, rocket engine components, jewelry, food items, and houses etc. [4-8]. This process consist of three basic steps as depicted in Fig. 1

Recently, 3D printing has been extensively utilized in many countries, for the manufacturing of distinct types of open source designs relevant to the aerospace industries, recently, 3D printing has been extensively utilized in many countries, for the manufacturing of distinct types of open source designs relevant to the aerospace industries, aviation industries, automotive industry and healthcare industries etc. [9, 10]. In spite, there are still some drawbacks for the selection of 3D printing technology (high printer cost, slow built rate and increase unemployment etc.

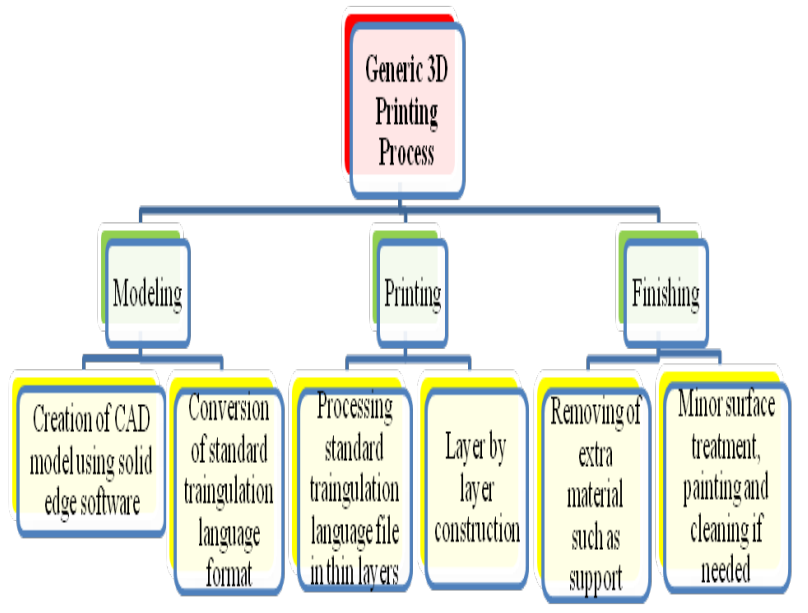

Fig.1 General Steps Involves In 3D Printing [5]

TABLE I THE EVOLUTION OF 3D METHODS

\begin{tabular}{|c|c|}
\hline Year of Inception & Technology \\
\hline 1770 & Mechanization \\
\hline 1946 & $1^{\text {st }}$ Computer \\
\hline 1952 & $1^{\text {st }}$ NC Machine Tool \\
\hline 1960 & $1^{\text {st }}$ Commercial Laser \\
\hline 1961 & $1^{\text {st }}$ Commercial Robot \\
\hline 1963 & $1^{\text {st }}$ Interactive Graphics \\
\hline 1988 & $1^{\text {st }}$ Comstem \\
\hline
\end{tabular}

But current $\mathrm{R}$ \& $\mathrm{D}$ have diminished the 3D printing machine cost. So that increasing its use in colleges, labs, and homes etc. [11]. The features of distinct 3D technology are illustrated in Table 2 
TABLE II FEATURES OF DISTINCT 3D PRINTING TECHNOLOGIES

\begin{tabular}{|c|c|c|c|c|c|c|c|}
\hline Method & $\begin{array}{c}\text { Process } \\
\text { Available }\end{array}$ & $\begin{array}{c}\text { Temperature } \\
\text { needed }\end{array}$ & Principle & $\begin{array}{c}\text { Support } \\
\text { structure }\end{array}$ & Merits & Demerits & Energy Used \\
\hline SLA & 1887 & Very low & Photo curing & Required & $\begin{array}{l}\text { Fine resolution } \\
\text { \&High quality }\end{array}$ & $\begin{array}{c}\text { Limited materials } \\
\text { utilization, Slow } \\
\text { printing and costlier. }\end{array}$ & Laser \\
\hline LOM & 1990 & Low & $\begin{array}{l}\text { Paper/sheet } \\
\text { lamination }\end{array}$ & Required & $\begin{array}{l}\text { Decrease tooling } \\
\text { as well as } \\
\text { manufacturing } \\
\text { time, Used distinct } \\
\text { range of materials, } \\
\text { low cost and } \\
\text { Manufacturing of } \\
\text { big size structures }\end{array}$ & $\begin{array}{l}\text { Surface quality as } \\
\text { well as dimensional } \\
\text { accuracy are not } \\
\text { good, complex } \\
\text { shapes cannot built. }\end{array}$ & Laser \\
\hline FDM & 1991 & Low & $\begin{array}{l}\text { Melted } \\
\text { extrusion }\end{array}$ & Required & $\begin{array}{l}\text { Extremely low } \\
\text { cost, simplicity } \\
\text { and high speed }\end{array}$ & $\begin{array}{c}\text { Low mechanical } \\
\text { characteristics, } \\
\text { Limited materials } \\
\text { utilized. }\end{array}$ & Extrusion \\
\hline SLS & 1991 & Low & $\begin{array}{c}\text { Sintering/he } \\
\text { ating of } \\
\text { powders }\end{array}$ & $\begin{array}{l}\text { Not } \\
\text { required }\end{array}$ & $\begin{array}{c}\text { Fine resolution, } \\
\text { Product of high } \\
\text { quality }\end{array}$ & $\begin{array}{l}\text { Layer by layer } \\
\text { finishing, }\end{array}$ & Laser \\
\hline LENS & 1997 & Low & $\begin{array}{c}\text { laser } \\
\text { cladding }\end{array}$ & Required & $\begin{array}{c}\text { Build complex } \\
\text { objects }\end{array}$ & Low strength & Laser \\
\hline EBM & 2001 & High & $\begin{array}{c}\text { Sintering/he } \\
\text { ating of } \\
\text { powders }\end{array}$ & $\begin{array}{l}\text { Not } \\
\text { required }\end{array}$ & $\begin{array}{l}\text { Produce less } \\
\text { stresses in } \\
\text { components } \\
\end{array}$ & $\begin{array}{c}\text { Costlier and slow } \\
\text { process }\end{array}$ & $\begin{array}{c}\text { Electron laser } \\
\text { beam }\end{array}$ \\
\hline SLM & 2004 & High & $\begin{array}{c}\text { Laser } \\
\text { melting of } \\
\text { powders }\end{array}$ & Required & High quality & Slow printing & Laser \\
\hline
\end{tabular}

\section{CLASSIFICATION OF 3D PRINTERS}

On the basis of feedstock material used the 3D printers are divided into following three categories such as solid based (FDM), liquid based (SLA, IJP) and powder base (SLM, SLS, EBM) are illustrated in Fig 2.

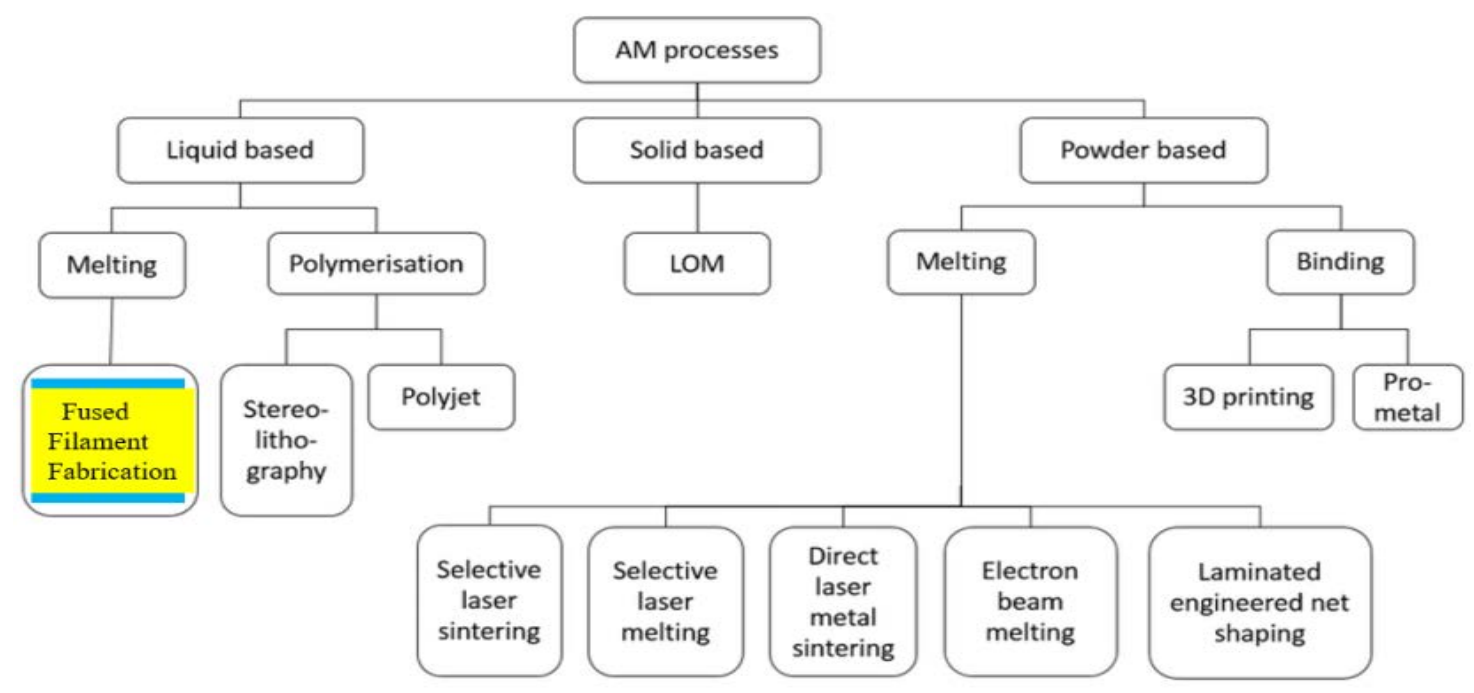

Fig.2 Distinct Types of Additive Manufacturing Methods

The several researchers/authors have used distinct 3D printing methods (SLS, SLA, EBM, FDM, IJP, SLM, etc.) for different applications and all these methods works on the same principle for manufacturing of final finished parts [27]. The schematic presentation of distinct 3D printer is illustrated in Fig 3(a-f). 

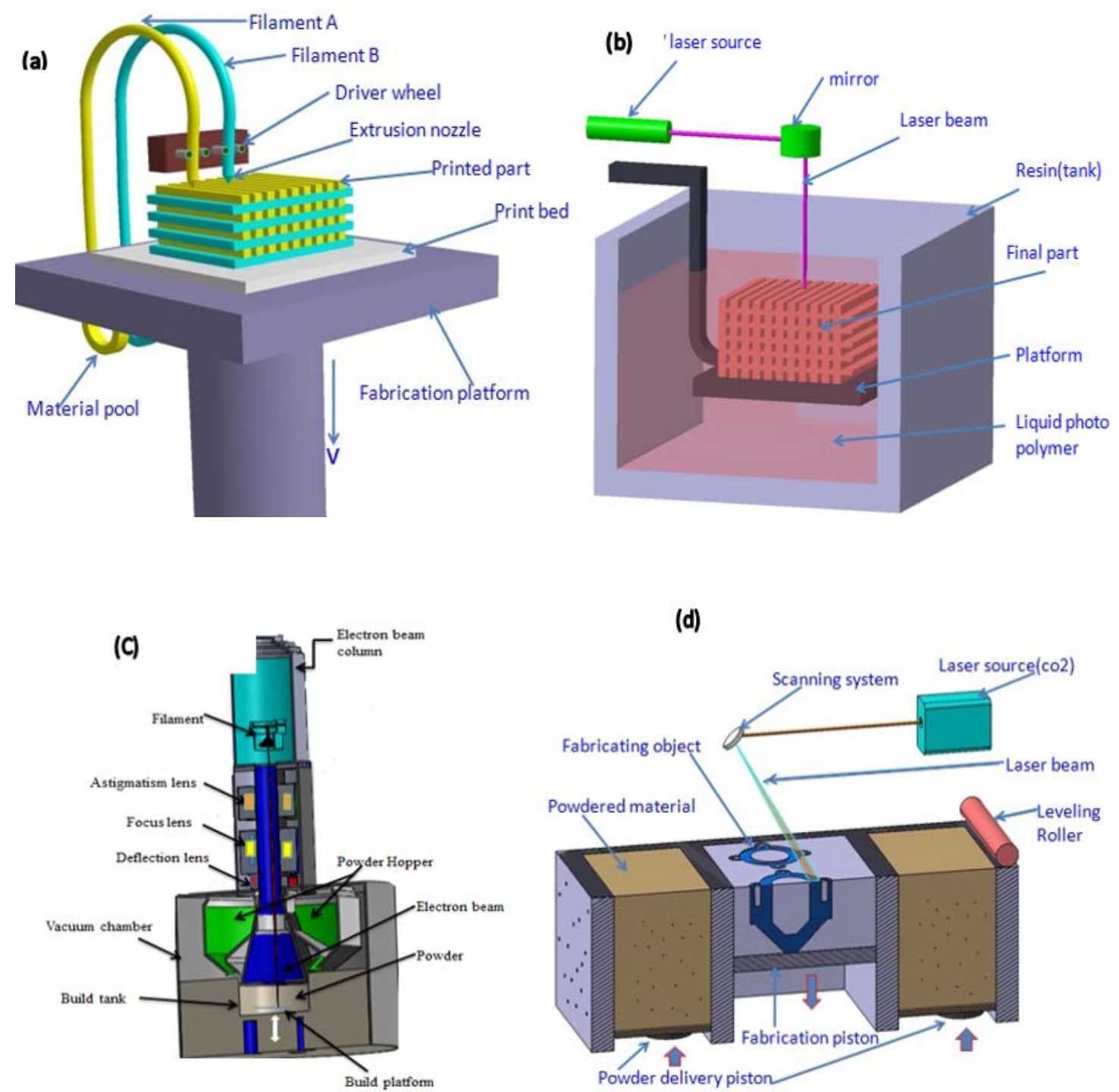

(d)
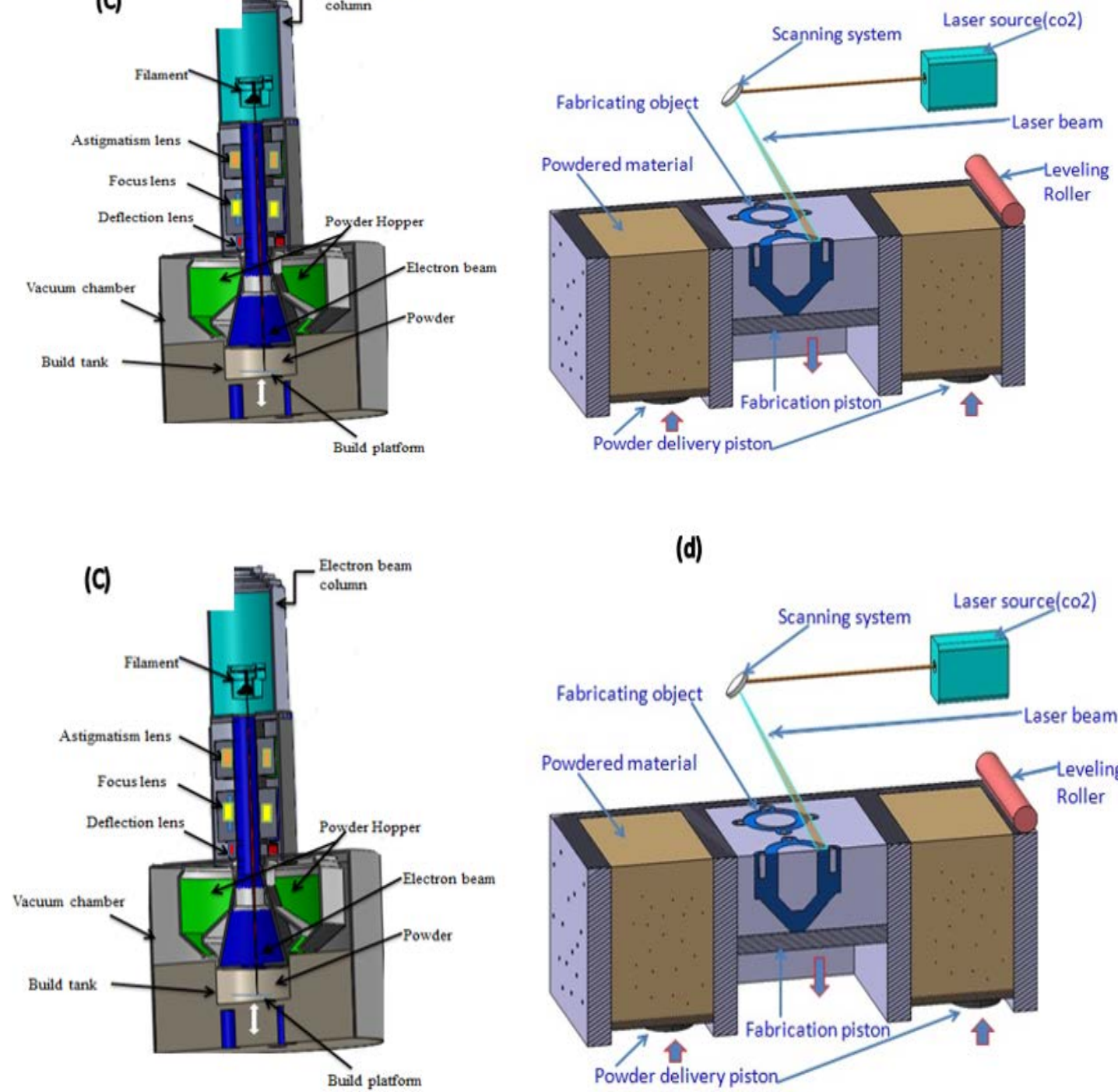

(d)

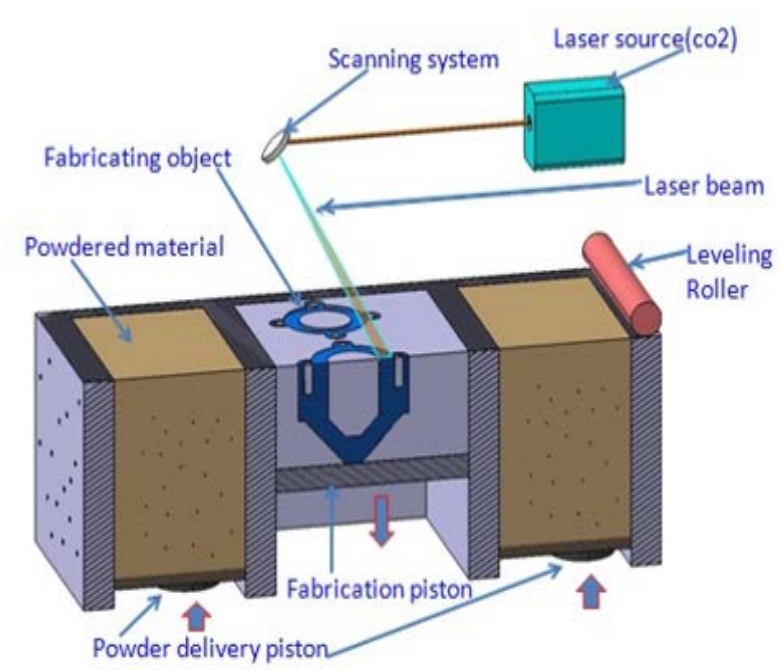


(e)

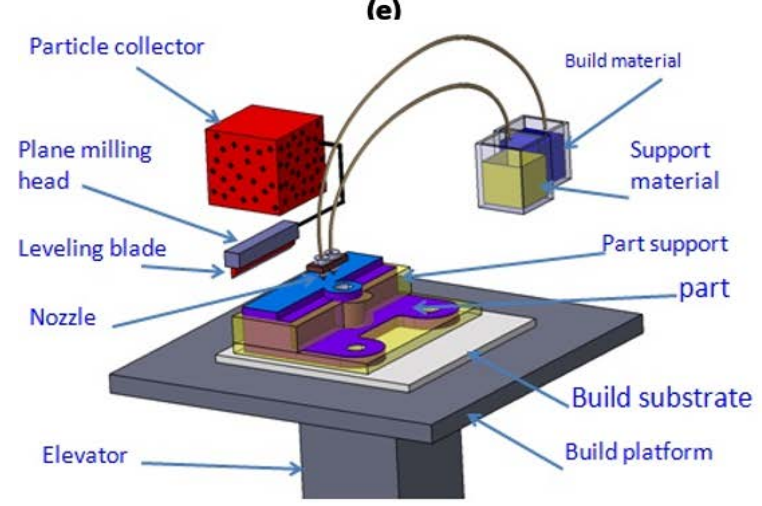

(f)

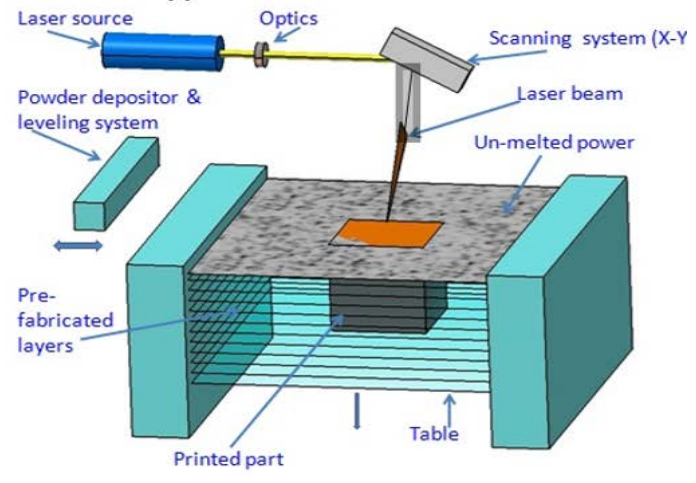

Fig. 3 (a-f) Schematic Diagram of Distinct 3D Printing Methods (a) FDM (b) SLA (c) EBM (d) SLS (e) IJP (f) SLM [27].

TABLE III DESCRIPTION OF DISTINCT 3D PRINTING METHODS

\begin{tabular}{|c|c|c|c|c|}
\hline Author/Year & Method & Material & Description & Ref. \\
\hline $\begin{array}{l}\text { Belhabib, S. et al. } \\
2017\end{array}$ & FDM & PLA, Nylon, ABS & $\begin{array}{l}\text { A thermoplastic material in the form of filament } \\
\text { is melted \& laid on to the build base in the form } \\
\text { of layer until the final part is formed. }\end{array}$ & [28] \\
\hline $\begin{array}{l}\text { Belhabib, S. et al. } \\
2017\end{array}$ & FDM & PLA, Nylon, ABS & $\begin{array}{l}\text { A thermoplastic material in the form of filament } \\
\text { is melted \& laid on to the build base in the form } \\
\text { of layer until the final part is formed. }\end{array}$ & [28] \\
\hline Liu, T. et al. 2018 & SLA & Photopolymers & $\begin{array}{l}\text { Laser beam of UV selectively hardens the photo } \\
\text { polymer resin in layers. Every layer is solidified } \\
\text { and built on top of next until the final part is } \\
\text { formed. }\end{array}$ & [29] \\
\hline $\begin{array}{l}\text { Nakao, Y et al. } \\
2014\end{array}$ & EBM & $\begin{array}{l}\text { Titanium, cobalt } \\
\text { chrome alloy }\end{array}$ & $\begin{array}{l}\text { The EBM 3Dprinting method is similar as that } \\
\text { of SLS, except for the high power electron } \\
\text { beam (EB) is utilized to fuse the powdered } \\
\text { constituent /particles. }\end{array}$ & [30] \\
\hline $\begin{array}{l}\text { Ligon, S.C. et al. } \\
2017\end{array}$ & SLS & Polyamide, nylon & $\begin{array}{l}\text { The high powder laser beam fuses the } \\
\text { powdered materials in layer fashion pattern to } \\
\text { form a component. }\end{array}$ & [31] \\
\hline $\begin{array}{c}\text { Mandrycky, C. et } \\
\text { al. } 2016\end{array}$ & IJP & $\begin{array}{l}\text { Starch or gypsum } \\
\text { (powder bed) and water } \\
\text { (binding agent) }\end{array}$ & $\begin{array}{l}\text { A liquid binding material is selectively dropped } \\
\text { into the powder bed in alternative layers of } \\
\text { powder binding liquid powder, until the final } \\
\text { component is formed. }\end{array}$ & [32] \\
\hline $\begin{array}{l}\text { Khan, M. et al. } \\
2010\end{array}$ & SLM & $\begin{array}{l}\text { metals, PC, Polymers, } \\
\text { ABS, powdered } \\
\text { plastics }\end{array}$ & $\begin{array}{l}\text { The molten state metal is solidified, as the laser } \\
\text { beam moves away from the melt pool. Each } \\
\text { layer is melted, enough to fuse it to the } \\
\text { underlying layer. Another powder material } \\
\text { layer of is then formed and spread onto the } \\
\text { earlier melted layer. }\end{array}$ & [33] \\
\hline
\end{tabular}

\section{APPLICATIONS OF 3D PRINTING IN DISTINCT SECTORS}

Additive manufacturing is now being utilized in a several distinct industries such as medical, automotive, fabric/fashion, aerospace, electronics, food, furniture, architecture, building and construction industry etc. The money spent yearly on final components fabricated by 3D printing worldwide and share of 3DP application in distinct sector are depicted in Fig 4(a\&b) respectively. 


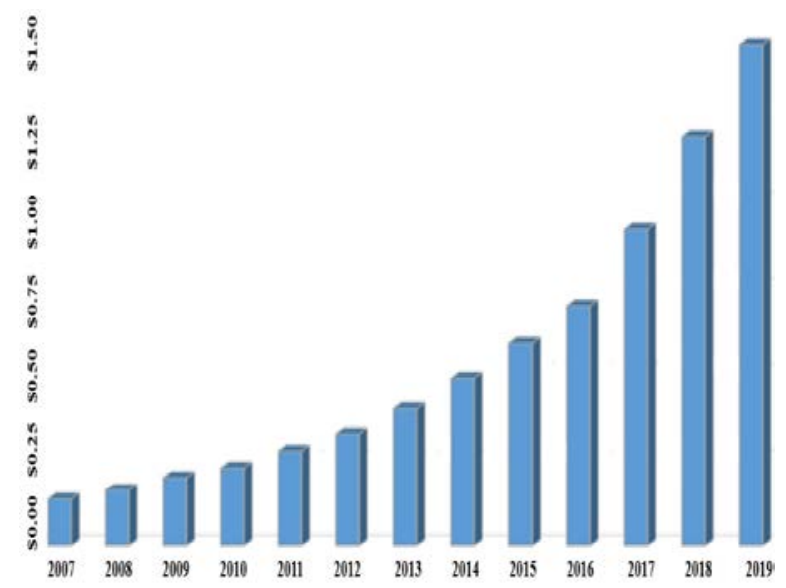

Fig. 4 (a) Money Spent annually on final component production by AM worldwide values are in billions of dollars. (Source: Wohler's Report 2020).

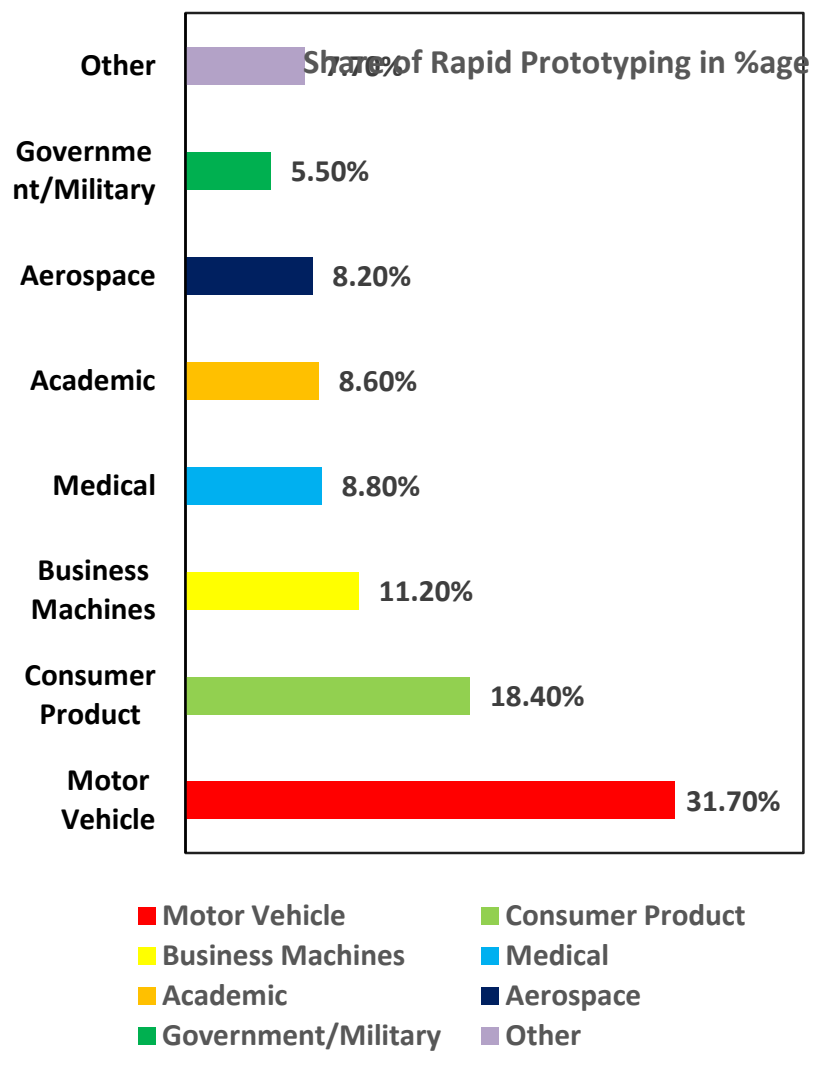

Fig. 4 (b) Share of Rapid Prototyping in Distinct Sectors [Wohler's Report 2020].

\section{A. Medical Industry}

The use of 3D printing is growing regularly, mainly in the medical field. The study reveals that about eleven percent of medical industries revenue comes from 3D components, whether medical device or implants [34]. The data obtained from web of science indicate that the total 1035 research papers of 3D printing for biomedical applications has been published from 2011 to till June, 2020 years. The distinct authors used distinct 3D printing methods in areas of medical for different applications such as custom made implant \& prosthetics, surgical tool, anatomical models, bio printing tissues and origins etc.[35-38]. The powder based process (SLS) process, facilitate/helps the fabrication of bone scaffolds, dental implants and medical devices while, solid based process (FDM) enable to fabricate surgical guides and bone models etc. respectively[39-42]. 3D printing provides greater customization as per the individual patient data which is obtained from laser scanning, ultrasound etc. and need for medical use. $[43,44]$. Now a day, 3D printing was used for the separation of Siamese twins by performing a correct pre surgical planning on 3D printer fabricated models, skull model and prosthetic leg respectively [44-47] as depicted in Fig.5.

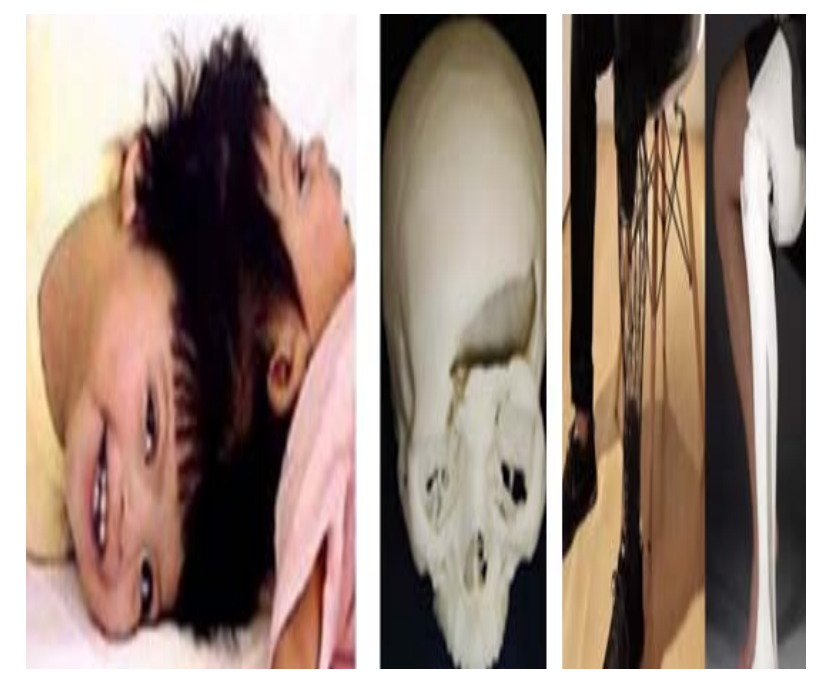

Fig. 5 Medical Applications: (a) Pre-Surgical Planning (b) Skull Model (c) Prosthetic Leg [44-47].

\section{B. Automotive Industry}

In the automotive industry, additive manufacturing has made miracle to bring new shines, robust designs, lighter, stronger and safer product in the short time [48, 49]. In this industry 3D printing applications are mainly found in an assembly line to assemble, light weight parts, replacement spare parts and prototypes [50]. Many car companies like BMW, Mercedes-Benz, Bugati, Honda, Toyata and Ford etc. are embracing 3D printing. The popularity of $3 \mathrm{D}$ printer is automobile industry has increased so rapidly over the past decade and the graph is expected to increase in oncoming financial years. The market value of 3D in this industry is predicted to reach USD 2391 million by 2022. 
Most of the car manufacturers that are using 3D printer have heightened the profitability and have secured the other revenue too [50]. According to the report of smart tech., only in 2019 the global automotive AM revenues is USD 1.4 billion and is predicted to increase to USD 5.8 billion by the year 2025 and have a $31.7 \%$ share in motor vehicles. There ia a lot of benefits of using a $3 \mathrm{D}$ printer in the automotive industry such as weight reduction, part consolidation and enhance the quality via rapid prototyping etc. Currently the main uses of automotive rapid prototyping are to manufacture valves, wind breakers, cooling vents, bumpers, and pumps, etc. The 3D printing is expected to be employed soon for fabrication of corrosion resistant super alloys [51, 52]. In addition, the 3D printing method can minimize the wastage materials, material consumption. Furthermore, 3D printing method can decrease time and cost. Hence, it provides to testing new designs in a fast timely. The application of 3D printing in automotive sector is depicted in Fig.6 [53-55].

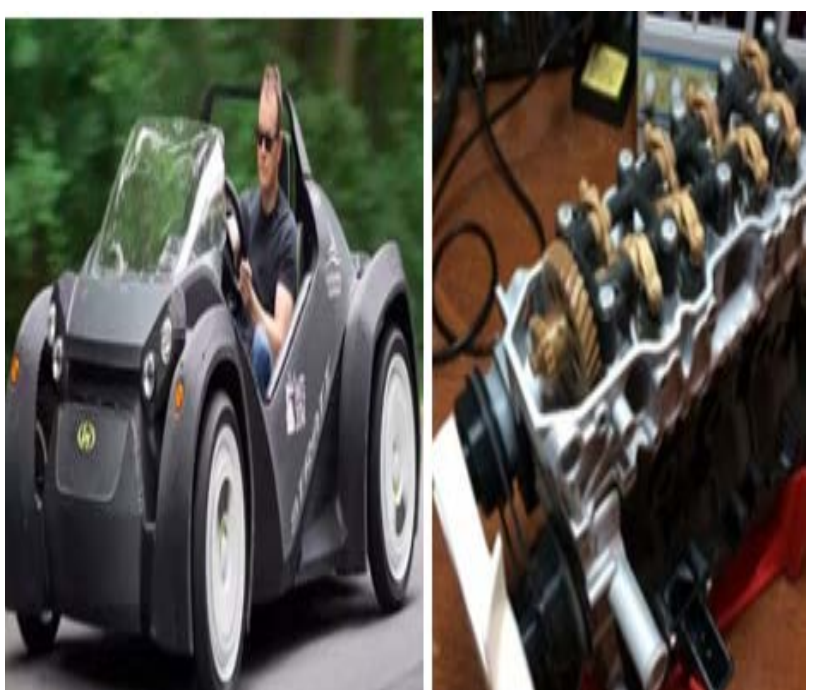

Fig. 6 Automotive application: (a) Toyota's i-Road vehicle(b) Toyota four Cylinder engine [55].

\section{Fabric and Fashion Industry}

The fusion of fashion and 3D printing may not sound like natural fit, but it is going to be part of everyday wears. Today 3D printing not only limit to the core of fashion industry, i.e. textile industry, its application is extending day by day, now it can print leather goods, accessories and many other [56]. 3D printing is utilized in the fashion industry to fabricate one-off complex design [58]. This technique has a great importance in many industries such as clothing, shoes, and jewellery industries.

In addition, the main merits of fabric \& fashion industries are lower supply chain cost, on-demand custom fit, deliver and produce products in less quantity with less time [59-61]. In fashion industry more often fused deposition melting (FDM), selective laser sintering (SLS) and polyjet AM technique are used, along with-it material is also required as input.

Mainly polymer, polymer composites material area used as it is lighter in weight and flexible for movement. For example: ABS plastic, PLA and PETG. These are the polymer having quality like printing durability of ABS material, dimensional accuracy of PLA plastic and PETG have water resistance and smooth surface finishing [62].

3D printing can provide a major tool to the artists and jewellers which will allow them to manufacture different shaped components in a very few hours than days [63].

\section{Aerospace Industry}

Aerospace Industry is one of the initials adopted of AM technology for prototyping, but now it is used to produce end parts as well as replacement parts [64]. The reason of adoption of 3D Printing in the aerospace industry is; that it has the capability to give support in energy saving and fuel economy idea from lightweight, quick production and reduce supply chain cost, etc. [49]. According to the earlier Wohler report 2017, the use of 3DP in aerospace is in the order of about USD 1 billion [64] Only Aeronautics sector is responsible for around 3\% of global green emission house gas [65].

It is predicated that the percentage would be increased to $70 \%$ by 2025 and $300 \%-700 \%$ by 2050 as compared to 2005. The international civil aviation organization and the international air transport has an ambitious reduction goal for air transport that reduction of $50 \%$ in net aviation $\mathrm{CO}_{2}$ emission by 2050, the adoption of additive manufacturing technology is the way to the goal by enhancing aircraft eco-design initiative [65]. Some benefits of additive manufacturing are as follow.

\section{E. Waste Reduction}

3D printing produces part by adding material only where it needed by layer on layer as a result, it produces less waste than traditional method. In aerospace industry very expensive material are used like titanium and different alloys which takes a lot of cost, effort, and time to recycle scarp producing during machining in traditional method. AM brings the scarp rate down to 10-20 percentage from 80-90 percentage [64], hence the cost time and effort are also saved by employing AM.

\section{F. Part Consolidation}

One of the key benefits of 3D printer is part consolidation. Additive manufacturing has ability to manufacture the multiple components as single component [64]. Part consolidation simplifies the assembly and maintenance process and effort [5].for example: GE additively manufactured its leap engine's fuel nozzle as a single part, ever it was made by 
assembling 20 different parts and is found 5 times more durable than the previous part [64].

\section{G. Maintenance and Repair}

Making maintenance, repair and overhaul MRO is an important function is an important function of the aerospace industry. Sometime MRO Company needs to produce or repair typical parts at a time and in this situation AM is very beneficial, not only this, in some situation MRO's company also have to produce the typical tool for any part that are not available to purchases from OEMs [64]. To do MRO, the MRO's company commonly uses metal 3D printing technologies like direct energy deposition. In addition, this technology provides many merits in aerospace sector, such as decrease fabrication cost ranging from $30 \%-35 \%$ in the case of low volume service components and decrease up to $70 \%$ product introduction lead-time [66]. Other applications of 3D printing are the prototyping complicated gearbox housing (for design examination), manufacturing of the engine block (cast metal) etc. [67]. In aerospace field 3D printing has shown more interest in these owing to fabricate direct metal components such as $\mathrm{Ti}$ and manufacture good performance items without the need of tooling [68].

\section{H. Electronics industry}

3D printing electronics provides high potential to build various functional 3D objects with complex feature, appearance, and properties. The engineers are working on structural, stretchable, conformal, embeddable and flexible electronics because the interest of persons is turning towards the wearable electronics, soft robotics, machines and human interference [69, 70]. Along with the extending in the application of 3D electronics, different multifunctional fabrication process is evolving like vat photo polymerization, material extrusion, power bed fusion, binder jetting, aerosol jetting, etc. [71].

However, nowadays hybridizing 3D printing process such as the combination of jet printing and extrusion, powder bed-based and aerosol jet printing (mostly used in electronics fabrication field) are is in trend [72]. All the above process required certain material like metal nanoparticle ink, adhesives, ceramics, bio-active matter, polymers and conductive inks and wire etc. to manufactures 3D structured object. This industry is interested to deliver something to a new generation, to catch the goal innovative technique and methods are using [73] like as mention above embedded electronics.

It is one of the recent progresses of $3 \mathrm{D}$ electronics that added significant functionality in printed structure also reduces the mass and assembly complexity. An embedded electronics circuit is fabricated with the help of stereolithographic (SL) and direct print (DP) together (a hybrid process). Similarly, as embedded electronics, stretchable and flexible electronics are also one of the recent progresses, which make possible to manufacture wearable electronics and soft robotics.

It is generally produced with the help of syringe extrusion-based 3D printing process $[74,75]$.

\section{Food Industry}

The healthy food, especially for pregnant ladies, patients, children, etc. is very essential [76]. By using 3D printing, the materials (high nutrients) can be mixed as well as processed into desired size and shape [77]. The major examples of food items which can be printed by this technology with desired shape are pizza, pasta, chocolate etc. [78]. Very soon a new kitchen appliance will be added in many kitchen rooms of the hotel, restaurant, homes, cafe, etc and the appliance is 3D printer. The 3D printer is so capable that it can now print food from ordinary meals to grow able and personalized nutrition [79]. However, food security and sustainable nutrition are the global agenda that should be considered during printing by 3D printer [80]. The food is printed through different technique and is basically categorized into 3 different categories they are extrusion-based printing, ink jet printing and binder jetting.

\section{J. Furniture Industry}

Today's 3D printing is trending around in all the industry. It has grave furniture industry too. In fact, it (3D printing) is making waves across this industry (furniture industry) by producing the novel form of furniture, connectors, replacement parts etc. [81].

As we know, furniture, play great role in decoration of home, hotel, office and etc. with different accessories like beds, coffee table, chairs and etc., to make stylish or to decorate that furniture 3D printing play great role [82]. Not only for decoration, but also save time, cost, etc. by eliminating or reducing has the assembly worked which took lots of time in the traditional method [83].

The material like thermoplastic, metal alloy, aluminium, plastic, PLA, ABS, stainless steel, polymer, etc. are used to make furniture and accessories, apart from this wood polymer, wood chip, saw dust are also used as material [83].

The 4XYZ company uses wood instead of saw dust powder or wood fibre to make product with a précised dimension shape and location. Sawdust; which is wood fiber that acts as raw material for different types of 3D printing technique like FFF. These types of material have great role in environment impact, reducing price, increasing performance and the printed product could be sanded, sainted, and painted like normal product [84]. 
Architecture, building, and construction industry. This technology is considered as eco-friendly derivative. In case of the construction industry, this technology can be utilized to print whole building of manufacture components [85]. The other merits of this technology are the companies can create/design the visual of the building economically, very less time and pinpoint problem areas. The most common examples of 3D printer buildings are Apis Cor Printed House in Russia and Amsterdam (Canal House) etc. [86, 87].

The architects generally 1st make their models by performing manually, that take more times and cannot fabricate complicated shapes of the object.

If we compare to other processes the SLA is most suitable for architectural modelling owing to its printing materials availability and resolution. In addition, the designs can be enhanced easily by simply amending the computer aided design model [88].

\section{K. Jewellery Industry}

Jewellery is one of the ancient and a well-known human art which is also considered as the wealth and aesthetic. Initially, some precious stone and metals are only considered as the material for jewellery, but today many other materials are added like stainless steel, bronze, copper, plastic, metal alloy and other precious metals like platinum, palladium, etc. Similarly, the application of the jewellery is also expanding e.g.Jewellery like bracelets, necklace, etc. are imbedding in fabrics, clothes, etc. for fashion [89].

There are many waysof making jewellery, but in market mostly 2 method are mostly used. i.e. Investment Casting and Direct printing (a 3DP method). Which are briefly explains below.

Today's investment casting begins with the designing through CAD software then it is transfer to the 3D printing machine like SLA, DLP, DOD, etc. According to the properties required of the product these techniques are selected. The machine then prints the pattern, for patterning mostly wax, castle resin is used. Thereafter, it is coated with clay, ceramics, etc. after it the wax is taken out by melting it.

After that, the liquefied metal is poured into it and left for cool. Finally, the coated clay is then removed. The second one is direct printing; in this method SMLS/SLM is used.

Same as IC, this method also starts with designing and transferring the STL to machine. The machine is then prepared for orientation of support, sized, shape, etc. and heated. Then the piece is sintered after it the product made is extracted from the supported, then finally sent to the post processing.
Both the methods have their own pro and cons in this industry. The DMLS technique has given the freedom on concepts and geometries, improve the time-to-market, high quality of output and sustainable design.

But in this method temperature should be preciously maintained, if the temperature is high then there is more chance to get the damage the parts or increase the work of post processing. It is expensive than IC. Similarly, IC has their own benefits like IC have potential to produce very high quality, detailed and minute, intricate feature. It is very beneficial for mass production [90].

\section{MERITS AND DEMERITS OF ADDITIVE MANUFACTURING}

\section{A. Merits}

1. 3D printing decreases the part production time and cost.

2. Fabricate customization implant.

3. In-Situ repair and In-Situ manufacturing are also possible with 3DP, which results in minimizing wastage.

4. It gives freedom in geometry, due to which the product with complex design can be easily produced that is moreover impossible with traditional manufacturing.

5. AM makes the product by adding the material so, the only required amount of material is used but with traditional way it just reverses. Hence, more material save, less wastage (in fact, no wastage) is produced, no environmental impact, etc. [91-93]

\section{B. Demerits}

1. Poor surface finish.

2. Less mechanical properties

3. In the study of Illinois Institute of Technology, It seems that some 3DP methods emit many harmful, toxic and carcinogen particle, which have a bad effect on health.

4. In future, it might reduce the manufacturing jobs for people, which latter invites many other social problems. Similarly, there will be a great issue of violation of copyrights. If anyone gets blueprint then they will easily counterfeit the product [93, 94].

\section{SUMMARY}

The results of some of the researchers who already used distinct 3D printing techniques in distinct sectors are summarized in Table 4

The results of some of the researchers who already used distinct 3D printing techniques in distinct sectors are summarized in Table 4 
TABLE IV THE SUMMARY OF DISTINCT 3D PRINTING METHODS, APPLICATIONS AND THEIR CONCLUSION

\begin{tabular}{|c|c|c|c|c|c|}
\hline Author & Year & Process & Application & $\begin{array}{l}\text { Conclusion } \\
\end{array}$ & Ref. \\
\hline $\begin{array}{l}\text { Ishack, S. } \\
\text { et al. }\end{array}$ & 2020 & $\begin{array}{l}\text { FDM, powder } \\
\text { bed fusion, ink } \\
\text { jet printing, etc. }\end{array}$ & $\begin{array}{l}\text { Medical } \\
\text { Industry }\end{array}$ & $\begin{array}{c}\text { N95 mask has 3D Printed, face shield property gained by } \\
\text { scanning the exact facial parameter, stable \& biocompatible } \\
\text { material, O2 control ventilator, pills. Hence this 3DP mask in } \\
\text { one of the best safety measure for respiratory syndrome like } \\
\text { COVID19 }\end{array}$ & [95] \\
\hline $\begin{array}{l}\text { Nerella, } \\
\text { V. N. et } \\
\quad \text { al. }\end{array}$ & 2016 & Extrusion based & $\begin{array}{l}\text { Construction } \\
\text { Industry }\end{array}$ & $\begin{array}{l}\text { It possess dual process i.e. buildability with the properties of } \\
\text { compressive, tensile, durable,etc. of the constructed body. }\end{array}$ & [96] \\
\hline $\begin{array}{l}\text { Singh, R. } \\
\text { et al. }\end{array}$ & 2020 & $\begin{array}{l}\text { Powder bed } \\
\text { fusion }\end{array}$ & $\begin{array}{l}\text { Aerospace, } \\
\text { Automotive, } \\
\text { Energy } \\
\text { Industry, etc. }\end{array}$ & $\begin{array}{l}\text { Despite of some limitation like roughing, cracking, etc. which } \\
\text { can be control by some process, it has great benefit over the } \\
\text { other AM technique. It is low cost, eco-friendly, some are } \\
\text { recyclable, good mechanical properties \& material like metal, } \\
\text { alloys, plastic, glass, etc. can be used. }\end{array}$ & [97] \\
\hline $\begin{array}{l}\text { Velázque } \\
\text { z, J. S. et } \\
\quad \text { al. }\end{array}$ & 2020 & FDM & $\begin{array}{l}\text { Medical } \\
\text { Industry }\end{array}$ & $\begin{array}{l}\text { The patient of Keratoconus is also able to take the benefit of } \\
\text { AM by using 3DP cornea with bio compatible material, low } \\
\text { cost, custom-made, light weight. Apart from this it gives } \\
\text { better and perspective treatment to the patient. }\end{array}$ & [98] \\
\hline $\begin{array}{l}\text { Beecroft, } \\
\text { M. }\end{array}$ & 2019 & SLS, FDM & $\begin{array}{l}\text { Fabric } \\
\text { Industry }\end{array}$ & $\begin{array}{l}\text { It possible for the AM to produce the knitted fabric that has } \\
\text { the properties nearly like in traditional fabric I.e. easily } \\
\text { stretchable, flexible, etc. Along this, continuous fiber type } \\
\text { geometry can be knitted easily. }\end{array}$ & [99] \\
\hline $\begin{array}{l}\text { Gha ff } \\
\text { S. H. et } \\
\quad \text { al. }\end{array}$ & 2018 & $\begin{array}{l}\text { Robotic arm \& } \\
\text { extrusion } \\
\text { nozzle nearly } \\
\text { like ink jet } \\
\text { printing } \\
\text { method, FDM, } \\
\text { SLS, SLA, etc }\end{array}$ & $\begin{array}{l}\text { Construction } \\
\text { Industry }\end{array}$ & $\begin{array}{l}\text { Construction with the help this technology gives the gives the } \\
\text { facility of customization, design-complexity, flexibility, low } \\
\text { cost, socio-economic, eco-innovative, etc. It has also main } \\
\text { role in developing model of complex and big project by the } \\
\text { help of FDM, SLS, etc. It is future of the construction } \\
\text { industry }\end{array}$ & [100] \\
\hline $\begin{array}{l}\text { Patel, K. } \\
\text { D. et al. }\end{array}$ & 2017 & DLP & $\begin{array}{l}\text { Construction } \\
\text { Industry }\end{array}$ & $\begin{array}{c}\text { For DLP, elastomer is very beneficial for printing highly } \\
\text { deformable complex 3D structure and fast processing without } \\
\text { any material support. Its uses is rapidly increasing in soft } \\
\text { robotics. }\end{array}$ & [101] \\
\hline $\begin{array}{l}\text { Cooper, } \\
\text { F. et al. }\end{array}$ & 2016 & DMLM/SLM & $\begin{array}{l}\text { Jewellery } \\
\text { Industry }\end{array}$ & $\begin{array}{l}\text { By using this technology in jewelry manufacturing increases } \\
\text { the production precious metals in medium \& small sized } \\
\text { enterprises to run the efficient business. Plus it has potential } \\
\text { for production of hollow profile, complex design, low cost, } \\
\text { less weight, etc. }\end{array}$ & [102] \\
\hline
\end{tabular}

\section{CONCLUSIONS}

3D printing technology has become a competent and advance manufacturing tool in different fields, including, automobile, medical, military, government, and aerospace, etc. Among these sectors, medical sector is an emerging sector in future due to customization, design flexibility, high accuracy, and ability to produce intricate parts. A lot of research in the medical sector to explore its new applications has been done. But some advance medical application such as organ printing is under progress.

\section{FUTURE SCOPE AND CHALLENGES}

In the future, researchers can explore the investigation to identify optimum parameter settings for specific 3D printing process and materials to obtain desired properties in the product. In addition, some research on lead time, product cost, and process capability of distinct type of 3D printing techniques can be performed for comparison and economic benefits.

The main challenges that $3 \mathrm{D}$ printing facing are as follows.

1. Intellectual property right of 3D printer user (for example pistol manufacturing)

2. Nearly anything can be printed by 3D printer and this is a troubling prospect, if criminals used 3D printer to create illegal product.

\section{REFERENCES}

[1] B.C. Gross, J.L. Erkal and S.Y. Lockwood, "Evaluation of 3D printing and its potential impact on biotechnology and the chemical sciences," Anal Chem., Vol. 86, No.7, pp.3240-3253, 2014.

[2] C. K. Chau, K. F. Leong and J. An, "Introduction to rapid prototyping of biomaterials," Rapid Prototyping of Biomaterials, Vol.2, pp. 1-15, 2020. doi:10.1016/b978-008-102663-2.00001-0 
[3] J. Horvath, "A Brief History of 3D Printing. In: Mastering 3D Printing,” A press, Berkeley, CA, 2014. https://doi.org/10.1007/978-1-4842-0025-4_1

[4] P. G. Thomas, 2018. Available: http://www.3ders.org/articles/20181001-paul-g-allensstratolaunch-space-venture-uses-3d-printing-to-developpga-rocket-engine.html.

[5] Thomas, 3D printed jellyfish robots created to monitor fragile coral reefs.3D Printer and 3D Printing News, 2018. [Online].

Available: http://www.3ders.org/articles/20181003-3d-printedjellyfish-robots-created-to-monitor-fragile-coral-reefs.html.

[6] G.E. Thomas, Transportation to produce up to 250 3D printed locomotive parts by 2025, 3D Printer and 3D Printing News, 2018 Available: http://www.3ders.org/articles/20180928-ge-transportationto-produce-up-to-250-3d-printed-locomotive-parts-by2025.html

[7] David, Available: https://www.3ders.org/articles/20180403mx3d-to-install-worlds-first-3d-printed-steel-bridge-overamsterdam-canal.html. [Accessed 2019],2018.

[8] Tess, Available: http://www.3ders.org/articles/20170412indian-jewelry-brand-isharya-unveils-infinite-petals-3dprinted-kewelry-collection.html. [Accessed 2019], 2017.

[9] O. Keles and E. Anderson, "Mechanical reliability of fused deposition modelling polymers and composite," Informatics, electronic and micro system, Vol. 23, pp.320-327, 2018.

[10] J. J. Beaman, J. W. Barlow and D. L. Bourell, "Solid Freeform Fabrication: A New direction in manufacturing, production and process engineering," Vol. 25, pp. 49-57, 2014.

[11] M. Jiménez, L. Romero, A.D. Iris and M. Domínguez, "Additive Manufacturing Technologies: An Overview about 3D Printing Methods and Future Prospects," Complexity, pp.1-30, 2019. doi:10.1155/2019/9656938

[12] L.J. Love, "Manufacturing Demonstration Facility (MDF)," Vol.4, pp.15-27, 2015.2http://dx.doi.org/10. 2172/1209199.

[13] B. Wendel, D. Rietzel, F. Kühnlein, R. Feulner, G. Hülder and E.Schmachtenberg, "Additive processing of polymers," Macromolecular Materials and Engineering, Vol. 293, No.10, pp.799-809, 2008. doi:10.1002/mame.200800121

[14] Construction Manager Magazine Skanska claims first with 3D printed cladding, September 2013. [Online]. Available: http://www.constructionmanagermagazine.com/news/skansk a-claims-industry-first-3dprinted-cladding/, Accessed date: 26 October 2016.

[15] DUS Architects, 3D Print Canal House, [Online]. Available: http://3dprintcanalhouse.com/Accessed date: 9 May 2016.

[16] Branch Technology, Cellular Fabrication, [Online]. Available: http://www.branch. Technology Accessed date: 2 February 2017.

[17] T.Wohlers and T.Gormet, "History of Additive Manufacturing," Wohlers report, Wohlers Associates INC., pp. 1-34, 2014.

[18] K. S. Tank and N. Lightdale, "Advances in 3d-printed pediatric prostheses for upper extremity differences," Journal of Bone and Joint Surgery, Vol. 98, No.15, pp. 1320-1326, 2016.

[19] X. Yang, D. ZHAO-WANG, GUO XUE-YI and T. L. Yong, "Towards a circular metal additive manufacturing through recycling of materials," A mini review Journal of Central South University, Vol.27, No.4,pp.1134-1145, 2020. DOI: https://doi.org/10.1007/s11771-020-4354-6.

[20] S. L. Sing, J. An, W. Y. Teong and F. E. Wiria, "Laser and electron beam powder-bed additive manufacturing of metallic Implants: a review on processes, materials and designs," Journal of Orthopaedic Research, Vol. 34, No.3, pp. 369-385, 2016.

[21] A. Cohen, A. Laviv, P. Berman, R. Nashef and J. Autair, "Mandibular reconstruction using stereolithographic 3dimensional printing modelling technology," Oral Surgery, Oral Medicine, Oral Pathology, Oral Radiology, and Endodontology, Vol. 108, No.5, pp. 661-666, 2009.
[22] D. Whitly, R. S. Eidson, I. Rudek and S. Bencharit, "Inoffice fabrication of dental implant surgical guides using desktop stereolithographic printing and implant treatment planning software: a clinical report," Journal of Prosthetic Dentistry, Vol. 118, pp. 256-263, 2017.

[23] F. Auricchio and S. Marocni, "3D printing: clinical applications in orthopaedics and traumatology," Effort Open Reviews, Vol. 1, No.5, pp. 121-127, 2016.

[24] D. Ibrahim, T. L. Broilo and C. Heitz, "Dimensional error of selective laser sintering, three-dimensional printing and PolyJet models in the reproduction of mandibular anatomy," Journal of Cranio-Maxillofacial Surgery, Vol. 37, pp. 167173, 2009.

[25] J. YU, M. Rombouts and G. Maes, "Material properties of Ti6Al4V parts produced by laser metal deposition," Physics Procedia, Vol. 39, pp. 416 - 424, 2012.

[26] H. Saijo, K. Igawa and Y. Kanno, "Maxillofacial reconstruction using custom-made artificial bones fabricated by inkjet printing technology," Journal of Artif.Organs. Vol.12, pp.200-205, 2009.https://doi.org/10.1007/s10047009-0462-7

[27] L.Zengguang, W. Yanqing, W. Beicheng and Chunzhi, “A critical review of fused deposition modeling 3D printing technology in manufacturing polylactic acid parts," The International Journal of Advanced Manufacturing Technology, Vol.5, pp.1-13, 2019. https://doi.org/ 10.1007/s00170-019-0332-x

[28] S. Belhabib and S. Guessasma, "Compression performance of hollow structures: From topology optimisation to design 3D printing," Int. J. Mech. Sci., Vol. 133, pp.728-739, 2017.

[29] T.Liu, S. Guessasma, J. Zhu, W.Zhang, H. Nouri and S. Belhabib, "Microstructural defects induced by stereolithography and related compressive behaviour of polymers,” Journal of Mater. Process Technol., Vol. 251, pp.37-46, 2018.

[30] Y. Nakao, Y. Wamoto, X. Gong, T. Anderson and K. Chou, Manufacturing Review Available at: 7 22, 2014. http://dx.doi.org/10.1051/mfreview/2014001.

[31] S.C. Ligon, R. Liska, J. Stamp, M. Gurr and R. Mülhaupt, "Polymers for 3D Printing and Customized Additive Manufacturing,” Chem. Rev., Vol.117, pp.10212-10290, 2017.

[32] C. Mandrycky, Z. Wang and K. Kim, "3D bioprinting for engineering complex tissues,” Biotechnol. Adv., Vol. 34, pp.422-434, 2016.

[33] M. Khan, P. Dickens and Selective Laser "Melting (SLM) of pure gold,” Gold Bull, Vol. 43, pp.114-121, 2010 https://doi.org/10.1007/BF03214976

[34] M. Javaid and A. Haleem, "Additive manufacturing applications in medical cases: A literature-based review," Alexandria Journal of Medicine, Vol. 54, pp. 411-422, 2018.

[35] R. Dhakshyani, Y. Nukman, A.N. Abu Osman and C. Vijay, "Preliminary report: rapid prototyping models for dysplastic hip surgery," Central European Journal of Medicine, Vol. 6 , pp.266-270, 2011.

[36] Q. Liu, M.C. Leu and S.M. Schmitt, "Rapid prototyping in dentistry: technology and application," International Journal of Advanced Manufacturing Technology, Vol. 29(34), pp.317- 335, 2005.

[37] F. Melchels,J. Feijen, and D.W. Grijpma, "A review on stereolithography and its applications in biomedical engineering," Biomaterials, Vol. 31, pp.6121-6130, 2010.

[38] R. Petzold, H.F. Zeilhofer and W.A. Kalender, "Rapid prototyping technology in medicine-basics and applications," Computerized Medical Imaging and Graphics, Vol. 23, pp.277-284, 1999.

[39] K. Leong, C.M.Cheah, and C.M. Chua, "Solid freeform fabrication of three dimensional scaffolds for engineering replacement tissues and organs., Biomaterials," Vol.24, 2363-2378, 2003.

[40] T.Traini, C.Mangano, R.L.Sammons, F.Mangano, A.Macchi and A.Piattelli,"Direct laser metal sintering as a new 
approach to fabrication of an isoelastic functionally graded material for manufacture of porous titanium dental implants,” Dental Materials, Vol. 24, pp.1525-1533, 2008.

[41] L.S. Bertol, W.K. Junior, F.P. Silva and C.A. Kopp, "Medical design: Direct metal laser sintering of Ti-6Al4V,” Materials and Design, Vol. 31, pp.3982-3988, 2010.

[42] Q. Liu, M.C. Leu and S.M. Schmitt, "Rapid prototyping in dentistry: technology and application, "International Journal of Advanced Manufacturing Technology, Vol. 29, No.3-4, pp. 317- 335, 2005.

[43] M. Javaid and A. Haleem, "Additive manufacturing applications in medical cases: A literature based review," Alexandria Journal of Medicine, 2017 doi:10.1016/j.ajme.2017.09.003

[44] J. Tuomi, K.S. Paloheimo and J. Vehviläinen, "Accuracy of medical models made by additive manufacturing (rapid manufacturing," Journal of Cranio-Maxillofacial Surgery, Vol.21, pp. 553, 2014.

[45] N. Tukuru, S.K.P.Gowda, S.M.Ahmed and S. Badami, "Rapid prototype technique in medical field," Research Journal of Pharmacy and Technology, Vol. 1, pp.341- 344, 2008.

[46] G. Domínguez-Rodríguez, J.J.Ku-Herrera and A. Hernández-Pérez, "An assessment of the effect of printing orientation, density, and filler pattern on the compressive performance of 3D printed ABS structures by fuse deposition," Int. J. Adv. Manuf. Technol. pp. 1-11, 2017.https://doi.org/10.1007/s00170-017-1314-x

[47] A. V. Do, B. Khorsand, S.M. Geary and A. K. Salem, "3D Printing of Scaffolds for Tissue Regeneration Applications," Advance Health Care Materials, Vol.5, pp.44-59, 2015.https://doi.org/10.1002/adhm.201500168

[48] Bill Artley. Automotive 3D Printing Application https://www.3dhubs.com/knowledge-base/automotive-3dprinting-applications.

[49] N. Shahrubudin, T.C. Lee and R. Ramlan, "An Overview on 3D Printing Technology: Technological, Materials, and Applications," Procedia Manufacturing, Vol. 35, pp. 12861296, 2019.

[50] Parupelli, S. kumar and Desai, "A Comprehensive Review of Additive Manufacturing (3D Printing): Processes," Applications and Future Potential, American Journal of Applied Sciences, Vol.16, pp. 244-272. 10.3844/ajassp.2019.244.272.

[51] A.S.Elakkad "3D Technology in the Automotive Industry, IJERT, pp.45-60. https://www.academia.edu/40991857.

[52] J. Bhattacharjya, J. Tripathi1, A. Taylor, M. Taylor and D. Walters, 2014 Additive Manufacturing: Current Status and Future Prospects Conference Paper in IFIP Advances in Information and Communication Technology, Vol.2, No.1 DOI: $10.1007 / 978-3-662-44745-1 \_36$.

[53] S. Kumar and A. Handa, "Combating hot corrosion of boiler tubes - A study. Engineering Failure Analysis,” Vol. 94, pp.379, 2018. doi:10.1016/j.engfailanal.2018.08.004

[54] V. Sreehitha, "Impact of 3D printing in automotive industry," International Journals of Mechanical and Production Engineering, Vol.5, No.2, pp. 91-94, 2017.

[55] A. Craig, Giffi.et al., "Cracking the genetic code of highperformance manufacturers," Deloitte Review 14, January 2014.

[56] Toyota.https://www.toyota.com.tr/world-of-toyota/conceptcars/i-road.json adresindenalınmıștırWoehler, T. (2017). Wohlers report 2017. Wohlers Associates. Wohlers Associates, 2018.

[57] N. Shahrubudin, T.C. Lee, R. Ramlan, "An Overview on 3D Printing Technology: Technological," Materials, and Applications, Procedia Manufacturing, Vol. 35, pp. 12861296, 2019.

[58] A. Vanderploage and M. Mamp, "The application of 3D printing technology in the fashion industry," International Journal of Fashion Design, Technology and Education, Vol. 10, pp. 170-179, 2017. http://dx.doi.org/10.1080/17543266.2016.1223355
[59] Tess, Indian jewellery brand Isharya unveils 'Infinite Petals' 3D printer jewellery collection, 3D Printer and 3D Printing News, 2017. [Online]. Available: http://www.3ders.org/ articles/20170412-indian-jewelry-brand-isharya-unveilsinfinite-petals-3d-printed-kewelry-collection.html.

[Accessed 2019].

[60] L. Gaget, 3D printed clothes: Top 7 of the best projects, Sculpteo.[Online].Available:https://www.sculpteo.com/blog /2018/05/23/3d-printed-clothes-top-7-of-the-best-projects/. [Accessed 2019],2018.

[61] M. Attaran, "The rise of 3-D printing: The advantages of additive manufacturing over traditional manufacturing," Business horizon, Vol.1, pp.1- 12, 2017.

[62] D. Sun and A.Valtasa, "3D printing in modern fashion industry,” JTSFT, 2019. https://irispublishers.com/jtsft/fulltext/3d-printing-inmodern-fashion, industry.ID.000535.php

[63] C.K. Chua, K.F.Leong and C.S. Lim, "Rapid prototyping: principles, applications," 2nd ed., World scientific, Singapore, 2003.

[64] Singamneni, Sarat and L. Yifan, Hewitt, A. Chalk, R.Thomas, W. Jordison and David, Additive Manufacturing for the Aircraft Industry: A Review,” 8. 1. 2017. 10.4172/2329-6542.1000214.

[65] Fares Mami, Jean-Pierre Revéret, Sophie Fallaha and Manuele Margni, "Evaluating Eco-Efficiency of 3D Printing in the Aeronautic Industry," Journal of Industrial Ecology, 2017, Vol. 21, No. S1, pp.537-548

[66] J. Coykendall, M. Cotteleer, J. Holdowsky and M.Mahto, 2014."https://www2.deloitte.com/us/en/insights/focus/3dopportunity/additive-manufacturing-3d-opportunity-inaerospace.html

[67] V. Raja, S. Zhang, J. Garside, C.Ryall and D. Wimpenny, "Rapid and cost effective manufacturing of high-integrity aerospace components," International Journal of Advanced Manufacturing Technology, Vol. 27, pp.759-773, 2006.

[68] I.Campbell, D. Bourell, and I. Gibson, "Additive manufacturing: rapid prototyping comes of age," Rapid Prototyping Journal, Vol. 18 No. 4, pp. 255258,2012. https://doi.org/10.1108/13552541211231563

[69] 3D opportunity for electronic, Dellotie University press, https://www2.deloitte.com/content/dam/insights/us/articles/ 3837_3D-opportunity-for-electronics/DUP_3D-OpportunityElectronics.pdf

[70] J. Lee, H. Kim, J. Choi and H. Lee, "A Review on 3D Printed Smart Devices for 4D Printing," 2017. https://www.researchgate.net/publication/318343531_A_rev iew_on_3D_printed_smart_devices_for_4D_printing.

[71] E. M. Donald and R. Wicker, "Multiprocessor 3D printing for increasing component functionality," Vol. 353, pp.4957, 2016 DOI: 10.1126/science.aaf2093http://science.sciencemag.org

[72] Alejandro Espera, John Ryan Cortez Dizon, Qiyi Chen, Rigoberto and C. Advincula, 3D-printing and advanced manufacturing for electronics, https://www.researchgate.net/publication/330855815_3D-

[73] J.A. Paulsen, M.Renn, K. Christenson and R.Plourde, "Printing conformal electronics on 3D structures with Aerosol Jet technology," Future of Instrumentation International Workshop (FIIW) Proceedings, pp.1-4, 2012.

[74] B.lu, H. Lan and H. Liu, Additive manufacturing frontier: 3D printing electronics," Journal of Opto-electronic advances, Vol. 01, No. 01, http://www.oejournal.org/ $\mathrm{J} / \mathrm{OEA} /$ Article/Html/A180209000001

[75] A. J. Lopes, Eric MacDonald and Ryan B. Wicker, Integrating stereolithography and direct print technologies for 3D structural electronics fabrication, 2018.DOI:10.29026/oea.2018.170004

[76] I. Dankar, M. Pujola, F. E. Omar, F. Sepulcre and A. Haddarah 2018 Food and Bioprocess Technology, "Procedia Manufacturing,” Vol. 35, pp. 1286-1296, 2019.

[77] Z. Liu, M. Zhang, B. Bhandari and Y. Wang (2017),“Trends in Food Science and Technology,” pp. 2-12. 2017. 
[78] L. Lili, M. Yuanyuan, C. Ke and Z. Yang, "Food and Bioprocess Technology,”, Vol. 35, pp.1-18, pp. 128612962018, 2018. Science Direct Available online at www.sciencedirect.com Procedia Manufacturing

[79] J. Jasper, “3D-Printed food,” , No.https://scholarship.law. umn.edu/mjlst/vol17/iss2/7, Minnesota Journal of Law, Science \& Technology, Vol. 17, No.2, pp.46-57, 2016.

[80] Pitayachaval, Paphakorn, Sanklong, Nattawut, Thongrak, Anantapoom, "A Review of 3D Food Printing Technology," MATEC Web of Conferences., Vol.213,2018. https://doi.org/10.1051/matecconf/201821301012

[81] Ways the Furniture Industry Benefits from 3D Printing, https://3dprinting.com/3d-printing-use-cases/how-thefurniture-industry-benefits-from-3d-printing/2019.

[82] 3D printed furniture on its way to homes of the future, https://www.sculpteo.com/blog/2018/02/21/3d-printedfurniture-appliances-of-the-future/

[83] Aydin, "Additive Manufacturing: Is It a New Era for Furniture Production," Journal of Mechanics Engineering and Automation, Vol.5, pp. 338-347, doi: 10.17265/21595275/2015.06.002.

[84] Interview: 4 AXYZ Explains How to 3D Print Wood Furniture, https://3dprinting.com/news/interview-4-axyzexplains-3d-print-wood-furniture/

[85] R. Bogue, "3D printing: the dawn of a new era in manufacturing?” Assembly Automation, Vol. 33, No. 4, pp. 307-311, 2013.

[86] M. Sakin, and Y. C. Kiroglu, "3D printing of buildinga: construction of the sustainable houses of the future by BIM,” Energy Procedia, Vol. 134, pp. 702-711, 2017.

[87] I. Hager, A. Golonka, and R. Putanowicz, "3D printing of building components as the future of sustainable construction?” Procedia Engineering, Vol. 151, pp. 292299, 2016.

[88] K.V.Wong, and A.Hernandez, A Review of Additive Manufacturing. ISRN Mechanical Engineering, 2012, 110,2012.

[89] Y.L.Yap, and W.Y. Yeong,“Additive manufacture of fashion and jewellery products: a mini review” Vol. 9, pp. 195-201,2014. http://dx.doi.org/10.1080/17452759.2014.938993

[90] T.Ferreira, H.A.Almeida, P.J.Bártolo and I.Campbell, “Additive Manufacturing in Jewellery Design," Advanced Manufacturing Processes; Biomedical Engineering; Multiscale Mechanics of Biological Tissues; Sciences, Engineering and Education; Multiphysics; Emerging Technologies for Inspection, Vol. 4, pp.4858. Doi:10.1115/esda2012-82789,2012.

[91] M.Attaran, "The rise of 3-D printing: The advantage of additive manufacturing over traditional manufacturing,"Business Horizions, Vol. 1399, pp. 1-12, http://dx.doi.org/10.1016/j.bushor.2017.05.011,2017.

[92] D.S. Thomas and S.W. Gilbert "Costs and cost effectiveness of additive manufacturing," NIST Special Publication, Vol. 1176, pp. 1-12,2014.

[93] S.Ford and M.Despeisse,"Additive manufacturing and sustainability: an exploratory study of the advantage and challenges," Journal of Cleaner Production, vol. 137, pp. 15731587, http://dx.doi.org/10.1016/j.jclepro.2016.04.150

[94] B.Berman,"3-D printing: the new industrial revolution," Business Horizons, Vol. 55, No.2, pp. 155-162,2012. doi:10.1016/j.bushor.2011.11.003

[95] S.Ishack and S.R. Lipner, "Applications of 3D Printing Technology to Address COVID-19-Related Supply Shortage" The American Journal of Medicine, Vol. 000, pp. 1-3,2020. https://doi.org/10.1016/j.amjmed.2020.04.002.

[96] V.N.Nerella, M. Krause and V. Mechtcherine, (date), “ Studying printability of fresh concrete for formwork free Concrete on-site 3D Printing technology (CONPrint3D)" journal, Vol. pp.

[97] R.Singh, A. Gupta,T. Ojestez, S.Srivastava, B. Singh, . A.AWasthi, S.K. Rajput, P. Sonia, P. Singhal and K.K Saxena, "Powder bed fusion process in additive manufacturing: An overview” Materials Today: Proceedings, Vol. xxx, pp. 1- 13,2020.https://doi.org/10.1016/j.matpr.2020.02.635

[98] Velázquez, J. S. Cavas, F. Bolarín, J. M. Alió, J. L., “3D Printed Personalized Corneal Models as a Tool for Improving Patient's Knowledge of an Asymmetric Disease” MDPI, vol. 12, pp. 1-12, doi:10.3390/sym1201015,2020.

[99] M. Beecroft, "Digital interlooping: 3D printing of weft-knitted textile-based tubular structures using selective laser sintering of nylon powder," International Journal of Fashion Design, Technology and Educatio, Vol.12 pp. 218-224,2019. https://doi.org/10.1080/17543266.2019.1573269

[100] S.H. Ghaffar, J. Corker and F. Fan, M., "Additive manufacturing technology and its implementation in construction as an eco-innovative solution" Automation in $\begin{array}{lllll}\text { Construction, } & \text { Vol. 93, pp. } & 1-11, & 2018 .\end{array}$ https://doi.org/10.1016/j.autcon.2018.05.005

[101] D.K. Patel, A. H. Sakhaei, Layani, M. et al, "Highly Stretchable and UV Curable Elastomers for Digital Light Processing Based 3D Printing,” Adv. material, Vol. 29, pp. 1-7,

[102] F. Cooper, "Sintering and additive manufacturing: "additive manufacturing and the new paradigm for the jewellery manufacturer." Progress in Additive Manufacturing, Vol.1, No.1-2, pp.29-43. 2016. 